\title{
Literacy Strengthening: A Case Study of Writing Class Program for Elementary School grade
}

\section{Umi Farkhatun}

Postgraduate Programs, Pendidikan Guru Madrasah Ibtidaiyah (PGMI), Institut Agama Islam Negeri (IAIN) Purwokerto, Central Java, Indonesia Email:umifarkha@gmail.com

\begin{abstract}
The low interest in reading Indonesian students as one of the literacy skills. As an alternative solution to this, effective literacy improvement programs are needed for elementary school students. This study aims to determine the method of child writer's class program as a program to strengthen children's literacy. The subjects were 20 child writer class participants. In this research, data was taken by a descriptive qualitative method. The object was from students who have in 7th and 11th years old. The program was done by organizes literacy activities such as seminars and writing training. Activities in this program emphasize a percentage of $30.0 \%$ of theoretical and $70.0 \%$ of writing practice. The results showed that the child in writing activity has strengthened literacy skills. It was caused because they understood the program. The program supported them to increase literacy skills especially writing. This is evidenced by the success of the program in publishing two anthology books written by 67 young writers.
\end{abstract}

Keywords: Literacy skill, young writer, student ability, writing program

\section{INTRODUCTION}

Literacy has several interrelated components, namely basic literacy, library literacy, media literacy, technology literacy, and visual literacy. Coverage of basic literacy skills includes the ability to listen, speak, read, write, and 


\section{Mudarrisa: Jurnal Kajian Pendidikan Islam, Vol. 12, No. 1, 2020}

count (Dikdasmen, 2016). Basic literacy skills are part of language skills in the school curriculum (Wilcox et al., 2020; Tarigan, 2015). Reading becomes one of the language skills that have an important role in language life (Safitri, 2019). If the intensity of reading is low, then other language skills such as writing, listening, and critical thinking will also be affected. Based on the explanation, it could be concluded that literacy is an integration of listening, speaking, writing, reading, and critical thinking skills (Priyatni, 2015). The essence of literacy is the activity of reading, thinking, then writing (Lin et al., 2018; Warsihna, 2016).

Literacy is needed by humans (Genlott, 2013). Especially for elementary school students in Indonesia as the next generation of the nation. But in fact, the ranking of Indonesian students' reading ability according to the Program for International Student Assessment (PISA) research was very low. Indonesia's ranking in this category ranks was $3^{\text {rd }}$ in the bottom of 41 participating countries with an average value of 371 in 2000 . The increase in the average value occurred six years later to 393 and ranked $48^{\text {th }}$ out of 56 participating countries. In 2009, Indonesian students' reading ability ranked $57^{\text {th }}$ out of 65 countries despite an increase in the average grade to 402 . This ranking dropped again in 2012 to $60^{\text {th }}$ from a total of 65 participating countries with an average value of 396 . The data shows the reading ability of Indonesian students is very alarming.

To overcome this situation, the Ministry of Education and Culture has made a regulation in the form of Minister of Education and Culture Regulation No. 23 of 2015 concerning the Growth of Character, 
Development Center, Language Development, and Development Agency. The Nation Literacy Movement or Gerakan Literasi Bangsa (GLB) as the flagship program of the regulation aims to improve the ability and interest in reading society. Another goal is to foster children's character through literacy culture (reading and writing). Library development as a source of information is also used as a way to foster and increase reading fondness (Ajisuksmo, 2019). According to Warsihna (2016), although the rules regarding the nation's literacy movement have been made by the government, they have not been encouraging. This is because until now the condition of literacy in reading and writing in Indonesian society especially students is still so minimal.

As a form of community support for the government, PKBM Ar Rosyid Purwokerto established a literacy strengthening program, called as" Kelas Penulis Cilik". The Kelas Penulis Cilik or Child writer class is a program that provides training for children in elementary school-age to actively write, especially short stories. This program aims to strengthen children's literacy skills in elementary grad early on. For this reason, it is necessary to research the program so that the method used as a means of strengthening children's literacy is known. After this research is carried out, it is hoped that the method will be useful for strengthening children's literacy culture and will increase their interest in participating in literacy strengthening programs. The results of this study can also be used as one solution to the problem of low interest in reading and writing Indonesian students. 


\section{Mudarrisa: Jurnal Kajian Pendidikan Islam, Vol. 12, No. 1, 2020}

Research on strengthening literacy was written by Anisa Shofiya entitled "Strengthening Student Literacy through Reflective Essay Writing: Implementation of Writing Programs for Reading in Higher Education" (Shofiya, 2017). Research on strengthening literacy was also carried out by Setiawan and Sudigdo in a journal entitled "Strengthening Literacy of Primary School Students through Library Visits". They argue that the library is one of the supporting literacy in which the school implements a planned and structured library visit program. This article also explains the stages of literacy planting (Setiawan, 2019). The difference between the two articles with the author's research lies in the object of research. Literacy strengthening activities studied by the author in the form of a program outside the school environment. From the author's research, a comprehensive method of supporting activities outside of school would be produced as a means of strengthening children's literacy. Besides, Andika's research emphasized on reading activities to increase reading interest, while child writers' class emphasizes more on writing activities to produce written.

Strengthening literacy for elementary school students certainly requires an interesting method and rarely discussed before. Activities that can stimulate students' interest in better literacy, such as child writer's class program. So, participants in the child writer class program at PKBM Ar Rosyid Purwokerto was observed well. Based on the explanation above, a problem formulation emerged, namely how the method of strengthening elementary school student's literacy through the program of child writers 
in PKBM Ar Rosyid to overcome the low interest in reading and writing of Indonesian students.

\section{METHODS}

This research used a descriptive qualitative method because it was done in natural settings and descriptive (Sugiyono, 2016). This study uses four stages of design in the form of pre-field, field activities, data analysis, and report writing. The first stage was the selection of research and licensing sites, initial observations, and preparation of research designs and preparing equipment used during the research process (Mangesti \& Subrata, 2018). The next stage includes data collection through observation, interviews, questionnaires, and documentation.

Sources of data in this study consisted of subjects and research objects. The subjects were students who were participants of the child writing class program in elementary grade by a total amount of 20 students at the elementary school level. There were the amount of 3 students who were still intensely participating in the program when the study was conducted. The object of this research is the activity in the child writer's class program. This study uses observation instruments that are used to find out the activities of child writers' class program from beginning to end in several meetings. The interview instrument or questionnaire was given to the founder as tutor, participants, and parents of program participants.

Documentation in the form of pictures and videos during the student writer's class. The next stage included observations, interviews, questionnaires, and documentation in the form of pictures and videos 
during the child writer's class. It was caused by interviews and questionnaires to have advantages and disadvantages of each, then using a combination of the two methods will bring better benefits.

The next stage was data collected where the source of data from the field will be analyzed so that the data can be concluded as a result of research. This study uses Miles and Hubberman's analysis in the form of data reduction, data display, and data verification. The fourth stage is the writing of reports in the form of the analysis of observational data, interviews, questionnaires, and documentation written in the form of research reports.

\section{DISCUSSION}

In this research, data analysis was done by interviewing and documentation by the naturalism process.

\section{Child Writer Class Program}

The child writer's class program was established in 2018. The purpose of forming a child writer's class is to provide facilities for children who interested in writing. The schedule for learning in child writers' class is held every Monday at $4-5.30 \mathrm{pm}$ at PKBM Ar Rosyid Purwokerto, Central Java region. Because there is no time limit in participating in the program, there were participants who follow it for only a few months and there are those who follow the program for up to one year.

When the child writers' class program was established, there were five children be participants. Subsequently, some participants left the 
program and enter another participant. The number of participants had increased to ten children who joined the program intensively. When this research was conducted, three children were still intensely participating in the program. In total, there have been twenty children who have participated in this program. The fee was given for 50.000 rupias per month and it was affordable for middle and upper economic families. Some children receive scholarships in the form of free education in the child writer's class for two months because their story scripts are selected by PKBM Ar Rosyid as the organizer.

Although this program has been socialized by word of mouth, give away, making posters or flyers, and through social media but it still experiences some obstacles. The obstacle is the absence of a special team that handles the program so that it still must be handled by the founder herself. On the other hand, PKBM Ar Rosyid has many other programs and this makes the program management not optimal. Another obstacle is the lack of interest of children in participating in the program. This is evident from the amount of 67 writers whose work is written in the anthology of short stories, only in percentage $29.0 \%$ of them who intensely taking part in child writers' classes. Even after their manuscripts were selected and received a free education in this program for two months it still did not add significantly to the participants.

Child Writers Class Participants.

This program was intended for children of elementary and junior high school age who have an interest in writing. When the study was 


\section{Mudarrisa: Jurnal Kajian Pendidikan Islam, Vol. 12, No. 1, 2020}

conducted, participants of the young writers class ranged in age from $7^{\text {th }}$ to $11^{\text {th }}$ years, as in elementary school grade. Students felt happy by joining the program because they made new friends. Besides, they were guided in a focus by teachers or tutors who are patient. Students used laptops when writing and successfully publish their work in a book. Participants have been fond of reading, writing, and telling stories since childhood. These hobbies have started in the first, second, and third class of the elementary school. This is evidenced by the collection of reading books that the participants already have, amounting to 90 copies. The collected books of participants were varied, ranging from textbooks, storybooks, poems, motivational books, anthology, novels, and even comics.

Some of the reasons participants took part in this program were wanting to publish their book while developing knowledge. They also have a curiosity about stories and how to make them. Besides, participants want to connect hobbies in the field of writing. Another reason is that they want to be able to convey kindness to everyone through their writing. Some participants took part in the program because they received a little coercion from their parents.

The parent's reason included their children in this program is to develop children's talents and creativity. Parents saw the potential and love of their children in the writing world. They wanted to reduce the intensity of children's interactions with gadgets. Parents want their children to have good writing skills with intensive guidance. They could channel children's hobbies. Some parents who have children who are 
closed and difficult to discuss want their children to put their thoughts into writing.

The source of inspiration for participants when writing comes from the experiences, readings, news, and life stories of people around them. The inspiration is also obtained from the daily events from their experience. The activities carried out in the child writers' class also inspired participants. Some of the obstacles faced by the participants during the activity and the process of producing work include the fact that when reading intensity decreases it will cause difficulties to think about themes. There are also difficulties when thinking of an idea about a short story conflict. Another difficulty experienced by the participants was when making the main idea and determining the right story title. That is because the participants felt they lacked ideas. When writing, participants feel often less careful about punctuation. The hardest obstacle is when there is a feeling of laziness to write because of decreased motivation and fatigue because of participating in other extracurricular activities.

Activities in the Child Writers Class Program.

Some of the programs that have been carried out by the child writer's class in addition to routine activities hold a children's story writing contest. This activity was held on 1st May of 2018 and $23^{\text {rd }}$ of December of 2018. Participants in this competition consisted of two categories. The first category is for students of elementary school grade $3-6$ and the second category is for students of junior high school grade $7-9$ specifically from 


\section{Mudarrisa: Jurnal Kajian Pendidikan Islam, Vol. 12, No. 1, 2020}

the Banyumas region area. 50 up to 60 of the best works have been recorded from this activity.

Another program is to hold a fable fairy writing contest. This activity was carried out on 4th August of 2019. Participants in the competition were not only intended for students from formal institutions in the Banyumas Regency area but also from non-formal institutions namely pursuing packages $\mathrm{A}$ and $\mathrm{B}$.

Book Review was held on November 25th, 2018 to coincide with the launch of the first anthology book entitled "Friendship Camp". This activity together with training in fun writing children's stories. The resource person in this activity was a teacher and writer named Thomas Utomo. The next program is training on writing fable fairy tales. This activity was carried out on July $14^{\text {th }}, 2019$ to coincide with the launch of the second anthology book entitled "Blue Ink Instructions". The resource persons in this activity were the writer of the novel Cinta Naik Tangga and the owner of the SIP Publishing publisher named Indra Defandra.

\section{Learning Methods in the Child Writer Class}

The learning method used in the young writers' class program applies theory in the percentage of $30.0 \%$ and $70.0 \%$ of the practice of writing directly. Writing skills not only require talent but also emphasize the existence of sustainable practice (Dalman, 2014). This method aims for students to make work in the form of children's stories or short stories and poems by typing directly on a laptop or paper for those who do not have a computer. The forms of learning activities in this program are: 
First, participants were read stories from children's books or magazines. Then the supervisor asks the participants one by one about the contents of the story that has been read like who the character is, and other intrinsic elements of the story. If the asking questions finished and all participants have answered, the supervisor gives theory and an overview of writing a story such as making an interesting title. This method is used to develop expressive language skills (Moore, 2014). Then, the participants were trained to use interesting words and sentences, correct punctuation, and were trained on how to use a laptop before starting practice.

Second, practice starts by asking inducement questions like "What activities did you do at school today?" Tell us about your experience." or "What are your activities like at home?" Reflective essay writing is applied to help strengthen literacy and increase motivation (Shofiya, 2017). After participants are accustomed to writing events, they are asked to make certain themed stories according to what they are interested in such as stories about friendship, adventure, fables, mysteries, and others. In the abstract children will write different things and bring out the uniqueness of their respective writing.

Third, the mentoring activity was more focused on each participant. The coach motivated and guide them through fun activities such as teaching editing and typing on a computer. After the practice is completed then an evaluation is conducted by the supervisor such as 
asking about the difficulties and challenges faced by the participants. The writing activity program was shown in Figure 6.
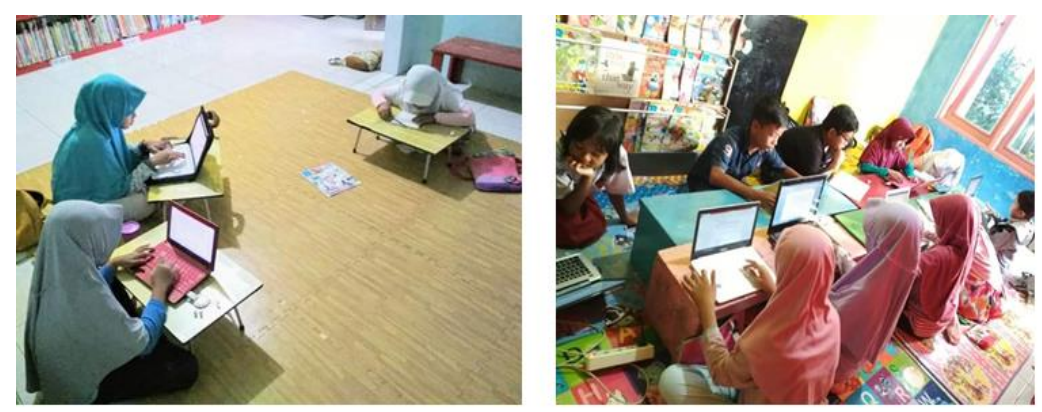

Figure 6. Writing Activity Program

The writing activity can support them in a lot of ability, including reading and also others. Their mentor will give directions to them on how to improve literacy ability. It caused, student's literacy can help them to increase their learning process (Fakhriyah et al., 2017).

Creation of Child Writers Class Participants.

The program has published two short story anthology books. The first book was titled "Friendship Camp". The first printing was published in October 2018 and contained 33 story titles written by 33 young writers. Some of the titles of the stories in this book are "Friendship Tree House", "Bathroom Mystery", "Surprise for Fairy Angelina", "Friendship Camp", and one titled was "Trail Adventure", and others. The second book entitled "Blue Ink Instructions" was published in January 2020 and contained 50 short story titles written by 50 young writers. Some of the titles of the stories in this book are "Helping Daughter", "Blue Ink Instructions", "My Brother My Best Friend", "Study Tour", "Just Best 
Friend", and others. Both of them were published by SIP Publishing Banyumas. The total authors of these two books consist of 67 students from 20 participants in the Child writer class program and 47 participants in the writing competition organized by this program. This book had printed 500 copies and his first book has been sold out and one of them was showed in Figure 7.

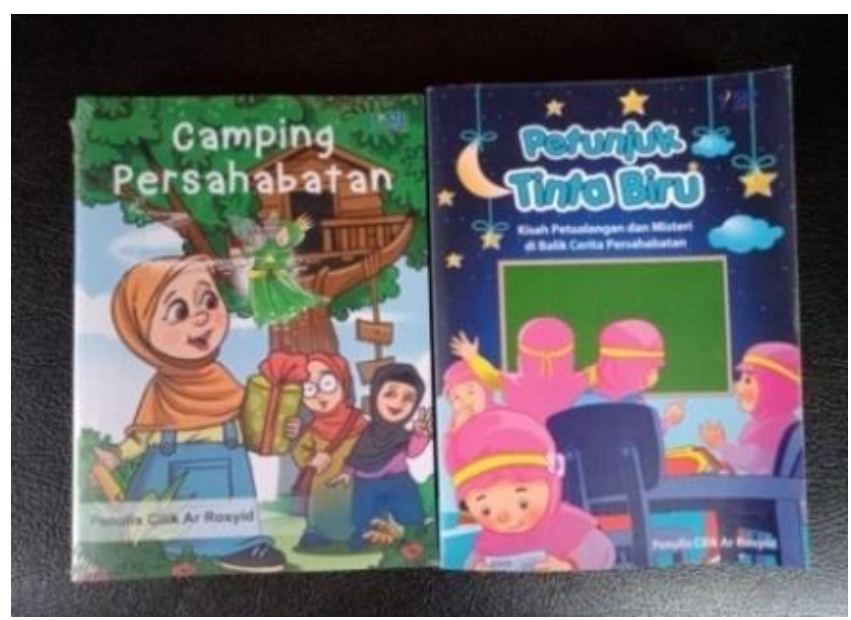

Figure 7. Anthology book was written by students

\section{Supporting Factors of Literation Culture Planting}

The success of planting and strengthening children's literacy from an early age cannot be separated from the role and support of parents (Zati, 2018). Parents of child writer class participants have tried to instill literacy culture in their children.

The methods to instill literacy culture in their children include: (1) Give support by introducing their children to books that are safe to hold and bitten both with pictures and striking colors and make the children enthusiast; (2) Frequent storytelling and reading stories with an expressive 
attitude so that children always ask to be read stories, especially before going to sleep; (3) When children begin to be able to read, parents begin to provide books at home that are requested by children to buy; (4) Give special time for children to read and write by getting children to write their experiences; (5) Motivate children if the mood of writing decreases through various activities such as inviting them to visit the regional library or museum; (6) Discuss the difficulties that children feel while writing and appreciate their work; (7) Remind, deliver, pick up and facilitate the children's needs during the literacy strengthening program; and (8) Provide a role model for reading to children. The total collection of books by parents of young writers who have reached in amount 400 and 800 copies. Some parents even work as librarians.

Parents hope by strengthening literacy through this program, children can find their true selves (Cho \& Lee, 2017; Temirova \& Westall, 2015). Besides, children are more honed at their writing talents and the more correct their writing procedures. The students could be more opened to others and able to apply their desires with maximum effort. The biggest hope is that children are more motivated to be more productive in writing so they can publish their works.

\section{Child Writer Class Program as a Means of Strengthening Literation Of Elementary School Students}

This child writer class program was very helpful and is closely related to literacy strengthening. This program makes participants able to write children's stories, develop ideas, package character messages into a story and understand the writing better and can describe the intentions and 
objectives in writing. Literacy strengthening must be done early and through this program, more children will be able to produce work and have achievements through their writing because this program provides intensive guidance to participants.

The benefits felt by the participants after joining the program include: Happier and more comfortable when writing; It was easier to understand the wisdom of an event; It was easier to explore ideas if asked by the teacher for writing assignments; After reading, you can get information and add vocabulary; The existence of mental development and perspective so that it is more sensitive and easy to receive goodness; Growing knowledge and understanding makes you more open and confident, and Gaining achievements in the literacy field. Achievements that have been achieved by the participants include works that have been published in children's anthology books, champions of poetry writing competitions, short story writing champions, children's story writing champions, and arithmetic mental competition champions.

The strength of this program is that it can facilitate children and help improve their literacy skills. Participants are more interacting and excited because they enter a community. Efficient learning time with affordable program fees also supports this program. The location of the study is strategic and close to the center of the city make it easy to reach. Besides, this program has a variety of activities that are fun and under the mindset of children. 
The weakness of this program is the lack of optimal management of the program due to a lack of tutors or supervisors. It only can facilitate children who already have an interest in the field of literacy. Besides, they have not been able to provide computer facilities for children who do not have them and cause a gap between participants.

\section{CONCLUSION}

Based on the data, it can be concluded that the child writer's class program methods could improve the student's literature interesting. Participants can do literacy activities with fun. This is evidenced by the success of the participants in producing work and feeling the benefits of this program. The literacy culture that has been instilled by parents in the home environment has been strengthened by the existence of this child writer class program.

The method of learning in child writers' classes begins with the activity of telling children's stories to participants. Next, ask the intrinsic elements of the story to the new participants then demonstrating the procedure for writing a story followed by giving feedback to the participants to write and practice story making accompanied by fun activities such as editing. The final activity was in the form of mentoring each participant more intensively. With this, the research was compiled for use by other authors as a reference. This research may not be full as expected by many parties. Hopefully, it can increase knowledge about 
methods of strengthening children's literacy. Future research is expected to complement the weakness of this research.

\section{REFERENCES}

Ajisuksmo, Clara R.P, at.al. (2019). Pelatihan Kerajinan Decoupage Sebagai Cara untuk Menumbuhkan Budaya Literasi Kaum Perempuan. Jurnal Abdimas Dewantara, 2(2), 158-170.

Cho, K., \& Lee, J. (2017). Influence of smartphone addiction proneness of young children on problematic behaviors and emotional intelligence: Mediating self-assessment effects of parents using smartphones. Computers in Human Behavior, 66, 303-311.

Dalman. (2014). Keterampilan Menulis. Jakarta: PT Raja Grafindo Persada.

Dikdasmen. (2016). Panduan gerakan Literasi Sekolah. Jakarta: Kemendikbud.

Fakhriyah, F., Masfuah, S., Roysa, M., Rusilowati, A., \& Rahayu, E. S. (2017). Student's Science Literacy in The Aspect of Content Science?. Jurnal Pendidikan IPA Indonesia, 6(1), 81-87.

Fakhriyah, F., Masfuah, S., Roysa, M., Rusilowati, A., \& Rahayu, E. S. (2017). Student's Science Literacy in The. Jurnal Pendidikan IPA Indonesia, 6(1), 81-87.

Genloot, Annika Angelii \& Ake Gronlund. (2013). Improving literacy skills through learning reading by writing: The iWTR method presented and tested. Computer $\mathcal{E}$ Education, 67, 98-104.

Kuen Yi Lin, S. C. L. (2018). Effect of Project-Based Activities in Developing High School Students' Energy Literacy. Journal of Baltic Science Education, 17(5), 867-877.

Mangesti P.R Dwi dan Heru Subrata. (2018). Penggunaan Media Gamelan Sederhana dalam Pembelajaran Tembang Dolanan di Kelas IV SDN Sumur Welut 1 Surabaya. Jurnal PGSD, 6(9), 1599-1609.

Moore, Wendy, at.al. (2014). "Strengthening Vocabulary for Literacy: An Analysis of the Use of Explicit Instruction Techniques to Improve Word Learning From Story Book Read-Alouds". Australian Journal of Learning Difficulties, 19(2), 153-172. 
Priyatni, E. T. (2015). Desain Pembelajaran Bahasa Indonesia dalam Kurikulum 2013. Jakarta: PT Bumi Aksara.

Safitri, Laela, at.al. (2019). Pengaruh Membaca 15 Menit Terhadap Minat Baca Siswa Sekolah Dasar. Jurnal Cakrawala Pendas, 5(2), 153-157.

Setiawan, Andika Aldi dan Anang Sudigdo. (2019). Penguatan Literasi Siswa Sekolah Dasar melalui Kunjungan Perpustakaan. Prosiding Seminar Nasional PGSD, $24-30$.

Shofiya, Arina. (2017). "Strengthening Students' Literacy Through Reflective Essay Writing: An Implementation of Writing to Read Program in Higher Education”. Jurnal Bahasa Lingua Scientia, 9(2), 281-292.

Sugiyono. (2016). Metode Penelitian Pendidikan Pendekatan Kuantitatif, Kualitatif dan R\&D. Bandung: ALFABETA.

Tarigan, H.G. (2015). Membaca Sebagai Suatu Keterampilan Berbahasa. Bandung: Angkasa.

Temirova, F., \& Westall, D. (2015). Analysis of First and Foreign Language Use in Content and Language Integrated Learning (CLIL) Classrooms. Procedia - Social and Behavioral Sciences, 178, 217-221. https://doi.org/10.1016/j.sbspro.2015.03.184.

Warsihna, Jaka. (2016). Meningkatkan Literasi Membaca dan Menulis dengan Teknologi Informasi dan Komunikasi (TIK). Jurnal Kwangsan, 4(2), 67-80.

Wilcox, M. J., Gray, S., \& Reiser, M. (2020). Early Childhood Research Quarterly Preschoolers with developmental speech and / or language impairment: Efficacy of the Teaching Early Literacy and Language ( TELL ) curriculum \&. Early Childhood Research Quarterly, 51, 124 -143. https://doi.org/10.1016/j.ecresq.2019.10.005.

Zati, Vidya A.D. (2018).Upaya untuk Meningkatkan Minat Literasi Anak usia Dini”. Jurnal Bunga Rampai usia Emas, 4(1), 18-21. 